\title{
RNA Synthesis in Porcine Blastomere Nuclei Introduced into in Vitro Matured Ooplasm
}

\author{
By P. Hyttel, R. Procházka, S. Smith, J. Kaňka and T. Greve
}

Department of Anatomy and Physiology and Department of Clinical Studies Reproduction, Royal Veterinary and Agricultural University, Denmark, and Institute of Animal Physiology and Genetics, Department of Genetics, Czech Academy of Sciences, Libechov, Czech Republic.

\begin{abstract}
Hyttel, P., R. Procházka, S. Smith, J. Kanka and T. Greve: RNA synthesis in porcine blastomere nuclei introduced into in vitro matured ooplasm. Acta vet. scand. 1993, 34, 159-167. - The objective was to investigate the RNA synthesis in porcine blastomere nuclei upon transplantation into in vitro matured enucleated oocytes. Nuclei from 2 - to 8 -cell porcine embryos were introduced into the ooplasm of in vitro matured and enucleated porcine oocytes by electrofusion, and the resultant reconstructed embryos were cultured in vitro. Before fusion or at different intervals after this event embryos were incubated with $\left[{ }^{3} \mathrm{H}\right]$-uridine, fixed, and histologically processed for autoradiography in order to detect RNA synthesis. About two thirds of the embryos were considered to depict normal development. All blastomeres displayed pronounced RNA synthesis before fusion, at 3 and $9 \mathrm{~h}$ after fusion the synthesis decreased or ceased, and at 24-49 $\mathrm{h}$ some embryos resumed synthesis at the 1- to 2-cell stage.
\end{abstract}

cloning; nuclear transfer; oocytes; embryos; porcine.

\section{Introduction}

Transplantation of blastomere nuclei is the cloning technique that currently offers the best prospects for widespread multiplication of single embryos. To date this procedure in farm animal species has resulted in live offspring in sheep (Willadsen 1986, Smith \& Wilmut 1989), cattle (Robl et al. 1987, Prather et al. 1987, Bondioli et al. 1990, Willadsen et al. 1991), and pigs (Prather et al. 1989). As used in farm animals the technique basically includes enucleation of metaphase II oocytes followed by fusion of the resultant cytoplast with a blastomere of the donor embryo whereby a reconstructed embryo is formed (Willadsen 1986). However, currently the efficiency is rather low particularly when using in vitro produced material (Chesne et al. 1991), and there are a number of cell biological mechanisms that need to be elucidated in order to improve the technique.

It is believed that certain products present in the cytoplast of the oocyte cause a reprogramming of the blastomere nucleus. In mammals however, only few facts are available concerning the nature of this reprogramming. Thus, it has been shown that hamster liver nuclei initiate DNA synthesis (Naish et al. 1987), that mice thymocyte nuclei are remodelled (Szöllösi et al. 1988), that rabbit (Stice \& Robl 1988) and pig blastomere nuclei (Prather et al. 1988 and 1990, Procházka et al. 1990) swell upon transplantation, and that lamin $\mathrm{A} / \mathrm{C}$ antigens, which are lost from the nuclei of the developing pig embryo by the 8-cell stage, reappear upon transplantation of 16cell stage nuclei (Prather et al. 1989). Re- 
cently, a report on the RNA synthesis of transplanted bovine nuclei has been published (Kaňka et al. 1991).

Early mammalian embryogenesis is characterized by an initial period of extragenomal control without RNA synthesis, relying entirely upon maternal stores of RNA. This period is followed by the maternal-embryonic transition during which the embryonic genome is activated and RNA synthesis initiated. The embryonic stage at which the bulk of the RNA synthesis is initiated is species specific, and it is among the large domestic species reported to be the 8-cell stage in cattle (Camous et al. 1986, Grøndahl et al. 1990) and the 4-cell stage in the pig (Tománek et al. 1989). Kan̆ka et al. (1991) recently reported that nuclei from 8-cell bovine embryos, which synthesize RNA, failed to incorporate ${ }^{3} \mathrm{H}$-uridine after fusion with enucleated oocytes. Moreover, it was shown on a very limited material that RNA synthesis did not resume in such reconstructed embryos until the 8-cell stage. These studies prompted us to investigate the incidence and timing of RNA synthesis in similarly reconstructed porcine embryos. Preliminary results from the present study have been presented earlier (Hyttel et al. 1990).

Thus, the objective of the present study was to investigate the RNA synthesis in nuclei from porcine blastomeres introduced into the ooplasm of enucleated metaphase II oocytes.

\section{Materials and methods}

Oocyte recovery, maturation and enucleation

Ovaries from prepuberal gilts obtained from a local slaughterhouse were transported at 20 $25^{\circ} \mathrm{C}$ to the laboratory within $2 \mathrm{~h}$ of collection. Small and medium sized follicles (1 to $4 \mathrm{~mm}$ diameter) were aspirated with a $20 \mathrm{G}$ needle into a syringe and the contents were deposited into a petri dish containing phosphate buffered saline (PBS) with $10 \%$ fetal calf serum (FCS).

Cumulus enclosed oocytes were recovered under a stereomicroscope and placed into 0.5 $\mathrm{ml}$ droplets of maturation medium consisting of TCM-199 supplemented with $20 \mathrm{mg} / \mathrm{ml}$ bovine serum proteins (USOL, Praque, Czechoslovakia) and then cultured for 38-42 $\mathrm{h}$ at $38^{\circ} \mathrm{C}$ in a $5 \% \mathrm{CO}_{2}$ and humidified air atmosphere.

Metaphase II oocytes with a discernible first polar body, spherical shape, and evenly granulated ooplasm were selected for enucleation. Micromanipulation was done in Whitten's medium (WM) supplemented with $7.5 \mu \mathrm{g} / \mathrm{ml}$ Cytochalasin B (Sigma, St. Louis, USA) and $10 \%$ newborn lamb serum (NLS). A cut was made in the zona pellucida adjacent to the polar body, and then the polar body and approximately one-third of the ooplasm was aspirated and discarded to manufacture cytoplasts.

Embryo recovery and blastomere manipulation

Prepuberal Yorkshire-Landrace gilts (90-105 $\mathrm{kg}$ ) were synchronized and superovulated with a gonadotrophin treatment consisting of 1200 I.U. PMSG (Antex ${ }^{\circledR}$, Leo Pharmaceuticals), followed in $72 \mathrm{~h}$ by $1000 \mathrm{IU}$ hCG (Physex ${ }^{\circledR}$, Leo Pharmaceuticals Ballerup, Denmark). Gilts were artificially inseminated at approximately 36 and $48 \mathrm{~h}$ after the hCG injection. Embryos at the 2- to 8-cell stages were surgically flushed form the oviducts at between 74 to $140 \mathrm{~h}$ post hCG administration. Embryos were briefly (1-2 $\mathrm{min}$ ) exposed to pronase (Sigma) at $37^{\circ} \mathrm{C}$ to cause partial digestion of the zona pellucida. They were then incubated in PBS without calcium and magnesium (Sigma) at $37^{\circ} \mathrm{C}$ for $15 \mathrm{~min}$ to reduce the bonding between blastomeres. While held in 
WM, $7.5 \mu \mathrm{g} / \mathrm{ml}$ Cytochalasin B, and $10 \%$ NLS a micromanipulator was used to free the blastomeres from the zona and to separate them from one another by repeated aspiration and expulsion from a pipette. Individual blastomeres from 2-, 3-, 4-, 6-, or 8-cell embryos were deposited into the perivitelline space of a previously prepared cytoplast. The reconstructed embryos were washed twice in WM plus $10 \%$ NLS and then equilibrated for $10-15$ min in $0.3 \mathrm{M}$ mannitol.

\section{Electrofusion and embryo culture}

Incorporation of blastomere nuclei into the cytoplasts was achieved by electrofusion in a fusion chamber (electrode distance $280 \mu \mathrm{m}$ ) containing $0.3 \mathrm{M}$ mannitol, $0.1 \mathrm{mM} \mathrm{MgSO}_{4}$ and $0.05 \mathrm{mM} \mathrm{CaCl}_{2}$ connected to a Krüss CFA 400 generator. Embryos were aligned in an AC field of $6 \mathrm{~V}$ and $600 \mathrm{kHz}$ for $5 \mathrm{sec}$ and a single DC pulse of $17 \mathrm{~V}$ and $100 \mu \mathrm{sec}$ duration was applied.

The embryos were removed, washed twice in WM plus $10 \%$ NLS and then cultured in the same medium in $0.5 \mathrm{ml}$ droplets at $38^{\circ} \mathrm{C}$ in a $5 \% \mathrm{CO}_{2}$ and humidified air atmosphere.

Before electrofusion $(0 \mathrm{~h})$, and at 3, 9, 24, and 44-49 h of culture $7,10,10,12$, and 16 reconstructed embryos, respectively, were incubated in WM plus $10 \%$ NLS enriched with 4 MBq ${ }^{3} \mathrm{H}$-uridine (UVVVR, Praque, Czechoslovakia) per $\mathrm{ml}$ for $20 \mathrm{~min}$ under the same conditions as described for embryo culture. At the end of incubation the embryos were washed 3 times in PBS with $10 \%$ fetal calf serum. Additionally, 2 reconstructed embryos that were collected before electrofusion, and which had both received donor blastomeres from 6-cell stages, were maintained in ${ }^{3} \mathrm{H}$-uridine free culture and served as controls.

Table 1. Developmental stage and degree of ${ }^{3} \mathrm{H}$-uridine incorporation relative to the time of fusion in embryos that were considered to depict normal development.

\begin{tabular}{|c|c|c|c|}
\hline \multirow{2}{*}{$\begin{array}{l}\text { Culture } \\
\text { after fusion } \\
\mathrm{h}\end{array}$} & \multicolumn{3}{|c|}{ Reconstructed embryos } \\
\hline & Developmental stage (number of nuclei) & Labelling & Number \\
\hline $0^{1}$ & Cytoplast (0) / Blastomere (1) & ++ & 4 \\
\hline \multirow[t]{2}{*}{3} & 1-cell (1) & & \\
\hline & 1-cell (anaphase) & & 1 \\
\hline \multirow[t]{2}{*}{9} & 1-cell (1) & - & 3 \\
\hline & 1-cell (1) & + & 4 \\
\hline \multirow[t]{4}{*}{24} & 1-cell (1) & + & 2 \\
\hline & 1-cell (metaphase) & & 6 \\
\hline & 2 -cells ( 1 per cell) & - & 1 \\
\hline & 2 -cells ( 1 per cell $)$ & ++ & 1 \\
\hline \multirow[t]{4}{*}{$44-49$} & 1-cell (1) & + & 2 \\
\hline & $1-\operatorname{cell}(1)$ & & \\
\hline & 2-cells (1 per cell) & ++ & 3 \\
\hline & 3 -cells (1 per cell) & - & 1 \\
\hline
\end{tabular}

1: Before fusion 


\section{Light microscopy and autoradiography}

All embryos were fixed in 3\% glutaraldehyde in $0.1 \mathrm{M}$ phosphate buffer for $1 \mathrm{~h}$ at $4^{\circ} \mathrm{C}$, post fixed in $1 \% \mathrm{OsO}_{4}$ in $0.1 \mathrm{M}$ phosphate buffer for $1 \mathrm{~h}$ at $4^{\circ} \mathrm{C}$, uranyl block stained, dehydrated, embedded in Epon, and serially sectioned into 1-2 $\mu \mathrm{m}$ semithin sections (Hyttel \& Madsen 1987). Specific sections including the nuclei and if present the nucleoli were selected by phase contrast microscopy and coated with Ilford K2 liquid emulsion (Ilford, Copenhagen, Denmark) and exposed for 4-5 weeks at $4^{\circ} \mathrm{C}$. Subsequently, they were developed with Kodak ID19 (Kodak, Copenhagen, Denmark) and fixed. Finally, all coated and uncoated sections were stained with $1 \%$ basic toluidine blue and evaluated by bright field light microscopy. The labelling of the coated sections due to incorporation of ${ }^{3} \mathrm{H}$-uridine was semiquantitatively scored as absent (-), moderate $(+)$, or pronounced $(++)$. For examples see Figs. 1a,b and 3a,b (++) and Fig. 2a,b $(+)$.

\section{Results}

A total of $35(66 \%)$ of the 53 embryos were considered to depict a normal course of development, which was defined as the presence of a single nucleus per cell and if cleavage had occurred, then symmetrical. All other embryos were considered as deviant. A presentation of the developmental stage and RNA synthesis of the normally developing reconstructed embryos after different periods of culture is given in Table 1. As no differences were noticed with respect to the effect of the developmental stage of the blastomere donor embryo on RNA synthesis the data from 2-, 3-, 6-, and 8-cell donor blastomeres were pooled.

None of the control embryos showed autoradiographic labelling.
Four of the 7 embryos fixed before fusion were considered as being normal. Each of the embryos had cytoplasts without chromosomes or nuclei, and the donor blastomeres, of which 1, 2, and 1 originated form 2-, 4-, or 6-cell donor embryos, respectively, displayed a central nucleus with pronounced autoradiographic labelling (Fig. 1a,b). The labelling was, as in all the following cases, seen dispersed over the nucleoplasm and not specifically associated with the nucleoli. The 3 deviant embryos had blastomeres without nuclei or chromosomes.

Seven embryos (all 1-cell) of the 10 fixed at 3 $\mathrm{h}$ after fusion were considered to be normal. In 6 of the embryos a spherical centrally located nucleus with moderate autoradiographic labelling was found (Fig. 2a,b), while the last embryo displayed an anaphase located slightly off center in the cell. Among the 3 deviant embryos 1 was binucleated, while fusion had not taken place in the last 2 embryos, both of which displayed nucleated cytoplasts.

Seven embryos (all 1-cell) of the 10 fixed at 9 $\mathrm{h}$ after fusion were considered to be normal. They all dispalyed a spherical centrally located nucleus with moderate $(\mathrm{N}=4)$ or no $(\mathrm{N}=3)$ autoradiographic labelling. The 3 deviant embryos, which were also 1-cell, were polynucleated or lacked nuclei or chromosomes.

Ten ( 8 one- and 2 two-cell) of the 12 embryos fixed at $24 \mathrm{~h}$ after fusion were considered as being normal. In 2 of the 1-cell embryos a spherical centrally located nucleus with moderate autoradiographic labelling was observed while the remaining 6 displayed metaphases, which were in general located in the center or slightly off center in the cell. The 2cell embryos had undergone symmetrical division, and each cell contained a spherical centrally located nucleus, which in a single 

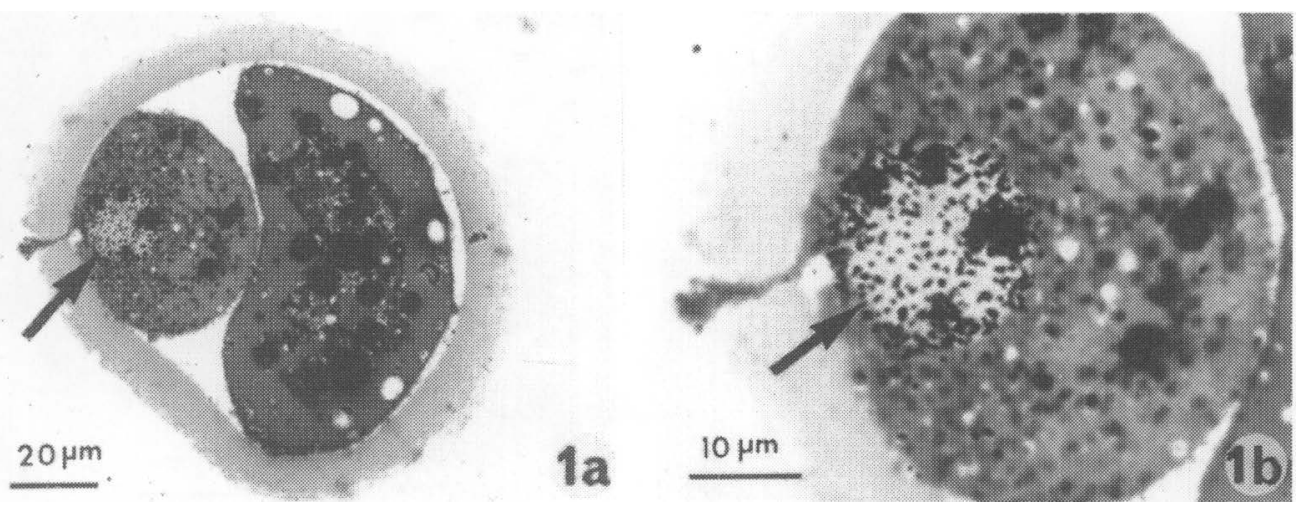

Figure 1a \& b: Reconstructed embryo before fusion. Note the pronounced $(++)$ autoradiographic labelling of the nucleus (arrow) of the blastomere, which originated from a 2-cell stage.
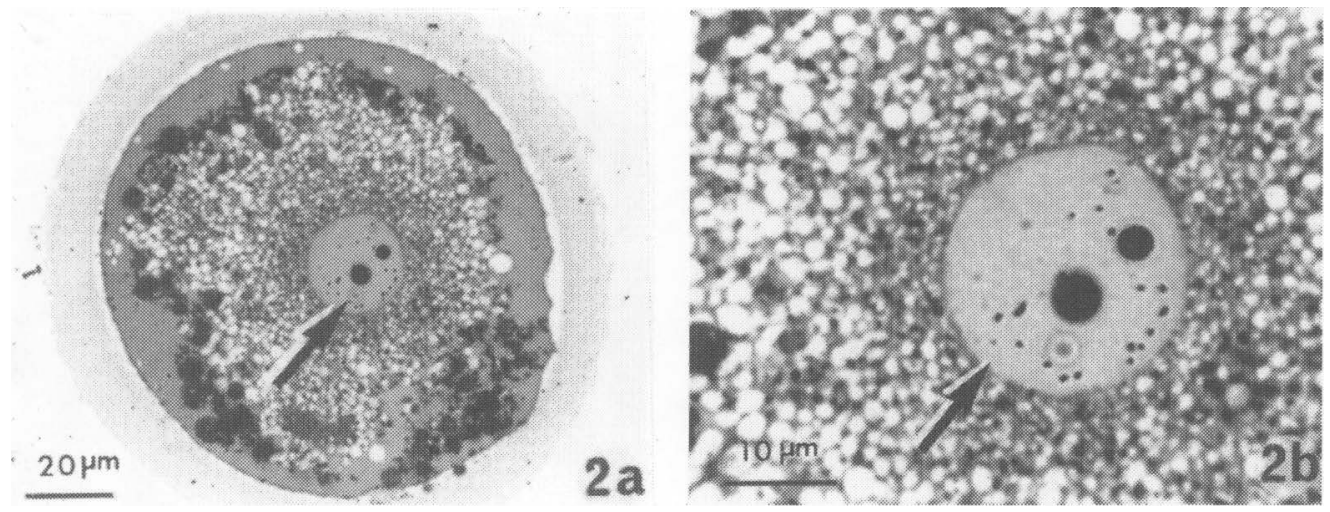

Figure $2 \mathrm{a} \& \mathrm{~b}$ : Reconstructed embryo $3 \mathrm{~h}$ after fusion. Note the moderate $(+)$ autoradiographic labelling of the centrally located nucleus (arrow).

embryo showed a pronounced autoradiographic labelling (Figs. 3a,b). The 2 deviant embryos, which were both 1-cell, lacked nuclei or chromosomes.

Only 7 ( 3 one-, 3 two-, and 1 three-cell) of the 16 embryos fixed at $44-49 \mathrm{~h}$ after fusion were considered as normal. The one-cell embryos displayed a spherical or slightly elongated nucleus with moderate $(\mathrm{N}=2)$ or pronounced $(\mathrm{N}=1)$ autoradiographic labelling. The 3 twocell embryos had undergone symmetrical division, and each cell contained a spherical nu- cleus displaying pronounced autoradio- graphic labelling. The normal 3-cell embryo had 1 large and 2 smaller cells each containing a spherical centrally located nucleus without autoradiographic labelling. The 9 deviant embryos, which were 1-, 2-, 3-, or 8-cell, either lacked chromosomes or nuclei completely in 1 or more blastomeres or they were bi- or polynucleated (Fig. 4a,b).

\section{Discussion}

In the present material about two-thirds of 

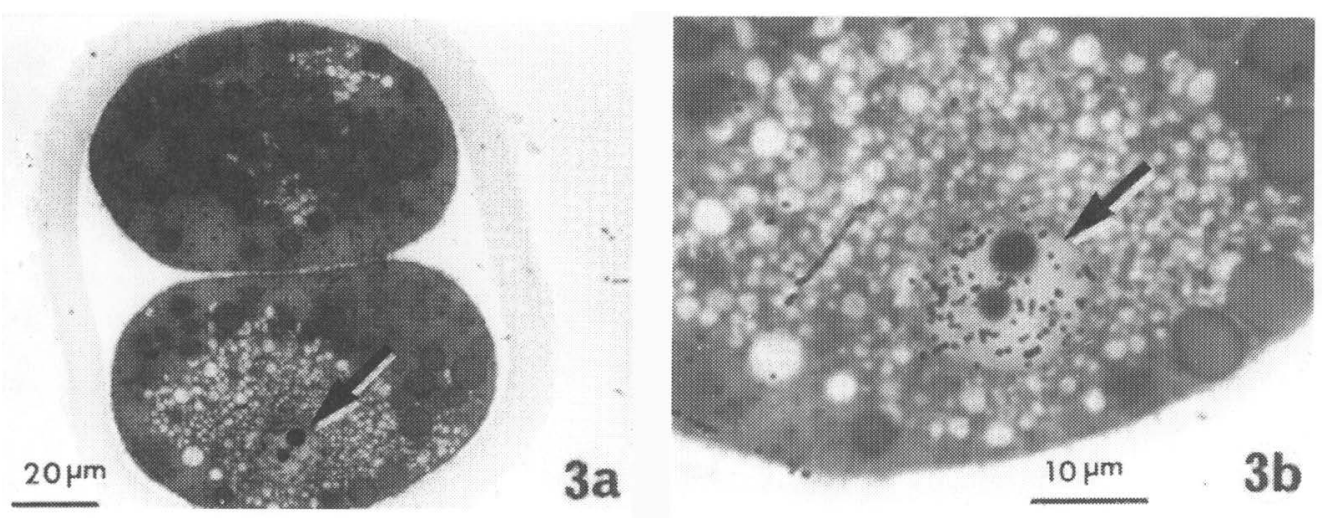

Figure 3a \& b: Reconstructed embryo at the 2-cell stage $24 \mathrm{~h}$ after fusion. Note the pronounced (++) autoradiographic labelling of the nucleus (arrow) in 1 of the blastomeres.
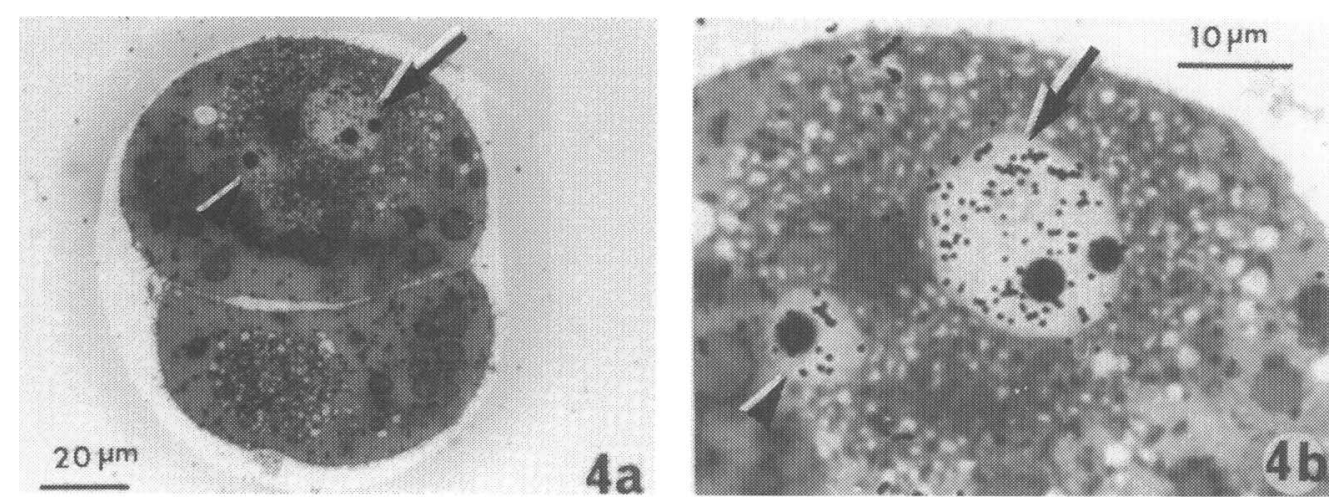

Figure $4 \mathrm{a} \& \mathrm{~b}$ : Deviant reconstructed embryo at the 2-cell stage $44 \mathrm{~h}$ after fusion. Note the pronounced (++) autoradiographically labelled large (arrow) and small (arrowhead) nucleus found in 1 of the blastomeres.

the reconstructed embryos were by morphological means considered as being normal. More than half of the embryos cultured for about 2 days displayed developmental deviancies, which was more than in any of the groups submitted to shorter culture periods. Using a similar culture system where FCS replaced NLS, 1- and 2-cell embryos were able to pass the 4-cell block at $81 \%$ although only $14 \%$ could develop to the blastocyst stage (Smith et al. 1992). Thus, the employed culture system is considered to be adequate in sustaining embryonic development through the short culture periods used in the present study. The poor rate of normal embryonic development, however, may reflect suboptimal activation of the recipient ooplasm by the employed single DC pulse. Such a stimulation appeared incapable of promoting an advanced parthenogenetic development of porcine oocytes matured in vitro (Prather et al. 1991).

It is noticeable that the morphological 
changes in the transplanted nuclei of the present study apparently is completely different from that described by Kaňka et al. (1991) in cattle. The latter authors observed a complete remodelling of the transplanted nuclei within the first $20 \mathrm{~h}$ after fusion including chromosome condensation, nuclear envelope breakdown, chromosome decondensation, and formation of a new nuclear envelope. This type of remodelling is similar to the one described by Szöllösi et al. (1988) upon transplantation of thymocyte nuclei into activated mouse oocytes. In the present material the transplanted nuclei were apparently not extensively remodelled, a feature that may be associated with a less complete reprogramming of the timing of embryonic development.

A complete nuclear remodelling requires presence of active maturation promoting factors (MPF) in the recipient cytoplasm (Szöllösi et al. 1988). The behaviour of the nuclei in the present study strongly suggest that active MPF was no longer operating in the recipient ooplasm at the time where the donor nucleus entered it. The drop in MPF activity must have occurred very fast since the fusion process did not exceed $30 \mathrm{~min}$ in our experiments. This observation raises the question whether such a rapid depletion of MPF molecules is an obligatory effect of electric activation. Recent results in cattle (Kaňka et al. 1991) and rabbit (Collas \& Robl 1991) clearly show that in vivo matured oocytes activated by an electric pulse preserve the capacity of sustaining complete remodelling of an introduced nucleus. Thus, in these cases a sufficient level of MPF activity was maintained until completion of the fusion process. We assume that the discrepancy in nuclear behaviour when transplanted into in vitro versus in vivo matured ooplasm is due to a lower level or less stability of MPF molecules produced in in vitro matured ooplasm. This feature is in accordance with the fact that in vitro matured porcine oocytes also are less capable in sustaining embryonic development following in vitro fertilization than in vivo matured ones (Yoshida et al. 1990).

All reconstructed embryos fixed before fusion displayed autoradiographic labelling over the nucleus of the donor blastomer including 1 embryo receiving a blastomere form a 2-cell stage. This finding is remarkable as previous studies have demonstrated that the onset of RNA production occurs at the 4-cell stage in unmanipulated in vivo derived pig embryos (Tománek et al. 1989). It is, however, possible that the blastomere isolation and manipulation performed in the present study before fixation and autoradiography has triggered RNA synthesis.

A clear pattern of RNA synthesis was seen in the reconstructed embryos depicting the course of normal development. Before fusion all blastomers showed a pronounced RNA synthesis, while at 3 and $9 \mathrm{~h}$ after fusion the synthesis had ceased or at least decreased markedly. At 24-49 h some embryos had resumed a high activity of RNA synthesis. A similar drop in RNA synthesis following fusion was observed in cattle (Kan̆ka et al. 1991). In the latter species, however, RNA synthesis was not resumed until the 8-cell stage, i.e. the stage at which the synthesis is initiated during normal unmanipulated embryonic development. The fact that the reconstructed embryos in the present study resumed RNA synthesis already at the 1- or 2cell stage may be due to a less complete reprogramming as also indicated by the less complete remodelling of the nucleus.

The fact that autoradiographic labelling was dispersed over the nucleoplasm rather than associated with the nucleoli suggests that the synthesized RNA is of the heterogeneous nu- 
clear type as also reported in cattle (Kaňka et al. 1991).

It is concluded that transplantation of porcine blastomere nuclei into in vitro matured ooplasm results in a drop in RNA synthesis, which is resumed within 1-2 days at the 1- to 2cell stage.

\section{Acknowledgements}

The authors thank Ms. Jytte Nielsen and Ms. Hanne Holm for preparing the autoradiographs and photographs, respectively. The work was supported by the Animal Biotechnology Research Centre.

\section{References}

Bondioli KR, Westhusin ME, Looney CR: Production of identical bovine offspring by nuclear transfer. Theriogenology, 1990, 33: 165-174.

Camous S, Kopečný S, Fléchon JE: Autoradiographic detection of the earliest stage of $\left({ }^{3} \mathrm{H}\right)$ uridine incorporation into the cow embryo. Biol. Cell. 1986, 58: 195-200.

Chesne P, Heyman Y, Peynot N, Desmedt V, Rao VH, Renard JP: Effect of in vitro or in vivo maturation of cattle oocytes on cleavage rate following nuclear transfer. 7th Scientific Meeting AETE 1991, p.136.

Collas P, Robl JM: Relationship between nuclear remodeling and development in nuclear transplant rabbit embryos. Biol. Reprod. 1991, 45: 455-465.

Grøndahl C, Madison V, Hyttel P, Avery B, Nielsen J, Greve T: Onset of RNA synthesis in bovine embryos after maturation, fertilization, and development in vitro. ARTA 1990, 1: 135-142.

Hyttel P, Madsen I: Rapid method to prepare mammalian oocytes and embryos for transmission electron microscopy. Acta anat. 1987, 129: 12-14.

Hyttel P, Prochazka R, Smith S, Kanka J, Greve T, $H \phi i e r R$ : Transcriptional activity of porcine blastomere nuclei introduced into in vitro matured ooplasm by electrically induced fusion. Theriogenology 1990, 33: 301.

Kaňka J, Fulka Jr. J, Fulka J, Petr J: Nuclear transplantation in bovine embryo: Fine structural and autoradiographic studies. Mol. Reprod. Dev. 1991, 29: 110-116.

Naish SH, Perrault SD, Zirkin BR: DNA synthesis following micro-injection of heterologous sperm and somatic cell nuclei into hamster oocytes.
Gamete Res. 1987, 18: 109-120.

Prather RS, Barnes FL, Sims MM, Robl JM, Eyestone WH, First NL: Nuclear transplantation in the bovine embryo: Assessment of donor nuclei and recipient oocyte. Biol. Reprod. 1987, 37: 859-866.

Prather RS, Sims ML, First NL: Nuclear transplantation in the early porcine embryo. Theriogenology 1988, 29: 290.

Prather RS, Sims MM, First NL: Nuclear transplantation in early pig embryos. Biol. Reprod. 1989, 41: 414-418.

Prather RS, Eichen PA, Nicks DK, Peters MS: Artificial activation of porcine oocytes matured in vitro. Mol. Reprod. Dev. 1991, 28: 405-409.

Procházka R, Smith S, Hyttel P, Greve T: Behavior of pig blastomere nuclei introduced into in vitro matured ooplasm by electrically induced fusion. Theriogenology 1990, 33: 301.

Robl JM, Prather R, Barnes F, Eyestone W: Nuclear transplantation in bovine embryos. J Anim. Sci. 1987, 64: 642-647.

Smith LC, Wilmut I: Factors affecting the viability of nuclear transplanted embryos. Theriogenology 1990, 33: 153-164.

Smith SD, Schmidt M, Purwantara B, Greve T: Oviduct epithelial cell-co-culture of early porcine embryos. Acta vet scand. 1992, 33: 349-355.

Stice SL, Robl JM: Nuclear reprogramming in nuclear transplant rabbit embryos. Biol. Reprod. 1988, 39: 657-664.

Szöllösi D, Czolowska R, Szöllösi MS, Tarkowski $A K$ : Remodeling of mouse thymocyte nuclei depends on the time of their transfer into activated, homologous oocytes. J Cell. Sci. 1988, 91: 603613.

Tománek J, Kopečný V, Kan̆ka J: Genome reactivation in developing early pig embryos: An ultrastructural and autoradiographic analysis. Anat. Embryol. 1989, 180: 309-316.

Willadsen SM: Nuclear transplantation in sheep embryos. Nature 1986, 320: 63-65.

Willadsen SM, Janzen RE, McAlister RJ, Shea BF, Hamilton $G$, McDermand $D$ : The viability of late morulae and blastocysts produced by nuclear transplantation in cattle. Theriogenology 1991, 35: 161-170.

Yoshida M, Ishizaki Y, Kawagishi H: Blastocyst formation by pig embryos resulting from in-vitro fertilization of oocytes matured in vitro. J. Reprod. Fert. 1990, 88: 1-8. 


\section{Sammendrag}

$R N A$ syntese $i$ svineblastomerkerner transplanteret til in vitro modnet ooplasma

Formålet med unders $\emptyset$ gelsen var at studere RNA syntesen i kerner fra svineembryoners blastomerer efter transplantation heraf til in vitro modnede enukleerede oocyter. Kerner fra blastomerer af embryoner på 2- til 8-cellestadiet blev overført til ooplasmaet fra in vitro modnede og enukleerede svineoocyter ved elektrofusion, og de rekonstruerede embryoner blev dyrket in vitro. Før elektrofu- sionen eller på forskellige tidspunkter herefter blev embryoner inkuberet med $\left[{ }^{3} \mathrm{H}\right]$-uridin, fikseret og histologisk præpareret til autoradiografi for at demonstrere mulig RNA-syntese. Omkring to trediedele af embryonerne vurderedes at udvikle sig normalt under dyrkningsforløbet. I disse embryoner udviste alle kerner markant RNA-syntese før elektrofusionen, 3 og 9 timer efter fusionen var RNAsyntesen hæmmet eller endog ophørt og 24-49 timer efter fusionen havde nogle embryoner på 1- eller 2cellestadiet genoptaget en høj synteseaktivitet.

(Received November 11, 1992; accepted January 6, 1993).

Reprints may be requested from: P. Hyttel, Department of Anatomy and Physiology, Royal Veterinary and Agricultural University, Bülowsvej 13, DK-1870 Frederiksberg C, Denmark. 